\title{
Optical Properties of Graptolite Epiderm - A Review
}

\author{
F. GOODARZI AND B. S. NORFORD
}

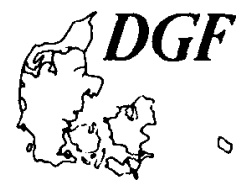

Goodarzi, F. and Norford, B. S. Optical properties of graptolite epiderm - a review. Bull. geol. Soc. Denmark, vol. 35, pp. 141-147, Copenhagen, July 1st, 1987. https://doi.org/10.37570/bgsd-1986-35-15

\begin{abstract}
Studies of optical properties of the skeletal materials of graptolites show progressive changes of reflectance, bireflectance, refractive index and absorptive index with maximum temperatures caused by depths of burial, metamorphism or tectonic disturbance. Samples of Lower Ordovician to Upper Silurian graptolites were selected from across Canada, at locations where the Conodont Alteration Indices of adjacent conodont collections provide temperature control. Maximum reflectance in oil and bireflectance appear to be the characters most diagnostic of maximum temperature and show progressively higher rates of increase at higher temperatures. These factors show potential for sensitive discrimination of temperatures at high levels of Conodont Alteration Indices.

Besides depth of burial, variables that have some effect on the optical properties include the composition of rock matrix, thermal metamorphism, mineralization and oxidation. The effects of morphological orientation and the taxonomical attributes of graptolites as yet are uncertain.
\end{abstract}

F. Goodarzi and B. S. Norford, Institute of Sedimentary and Petroleum Geology, 3303-33rd Street N.W., Calgary, Alberta T2L 2A7. August 29th, 1985.

\section{Introduction}

Graptolites are organic fossils that mainly occur in lower Palaeozoic (Ordovician-Lower Devonian) marine sediments. Vitrinite (kerogen type III, Brooks 1981) has been used in post-Devonian sediments to determine the thermal maturity of sedimentary rocks. Pre-Devonian sediments are devoid of vitrinite (Van Gijzel 1975, Goodarzi 1982) but may contain graptolite fragments that can be used to determine the maturation levels of the sediments (Kurylowicz, Ozimic, McKirdy, Kantlser \& Cook 1976; Clausen \& Teichmüller 1982; Goodarzi 1982, 1984, 1985b; Goodarzi \& Norford 1985; Goodarzi, Gunther, Jenkins \& Snowdon 1985).

\section{Morphology observed under reflected light}

The morphology of graptolites under reflected light has been described in several recent publications (Kurylowicz et al., 1976; Teichmüller, 1978; Goodarzi, 1982, 1984, 1985b; Goodarzi \& Norford, 1985). Kurylowicz et al. (1976) described graptolites as thin elongated bodies show- ing complex skeletal morphology. Teichmüller (1978) described in detail the morphology and microscopic structure of graptolite cortex as seen in polished sections. She showed that graptolites have a laminated cortex, the single lamellae possessing an ultra-fine fibrous structure which, however, becomes seldom visible in reflected light. The width and amount of the alternating light and dark lamellae (visible in polarized reflected light) may influence the maximum reflectance value under oil immersion. Goodarzi (1982) described the graptolite fragments found in lower Palaeozoic sediments from Turkey and compared their morphology to those of acritarchs, bitumen and chitinozoans.

\section{Equipment and methods}

Reflectances at our Calgary institute are measured using Leitz M.P.V. II or Zeiss MPM microscope-photometers fitted with a monochromator (400-700 nm) and connected to Apple (Leitz) or Zonax (Zeiss) microcomputers and printers. Reflectances have been measured mainly at the 546 $\mathrm{nm}$ wavelength, but dispersions of reflectance were determined in the visible spectrum (450-700 $\mathrm{nm}$ ) using a monochromator. 


\section{Sample preparation}

Relief-polished surfaces were prepared from sediments containing graptolites using standard procedures (Mackowsky 1982) except for a modification in the polishing of the samples by using three grades of alumina $(0.3$ and $0.05 \mu \mathrm{m})$ dispersed on wet blocks of wood. Reflectances of highly metamorphosed graptolites $(\% \mathrm{R}$ oil $=>10.0)$ were determined on their natural surfaces. Kwiecinska, Murchison \& Scott (1977) have stated that the reflectance of graphite measured on the natural surface was higher than the polished surface of graphite. Graptolites with reflectance of $>10 \%$ are in the semi-graphitic to graphitic stage (Teichmüller, Teichmüller \& Weber, 1979).

$$
\begin{aligned}
& \mathrm{n}=\frac{\left(\mathrm{no}^{2}-\mathrm{na}^{2}\right) / 2}{\mathrm{no}[(1+\mathrm{Ro}) /(1-\mathrm{Ro})]-} \\
& \mathrm{na}[(1+\mathrm{Ra}) /(1-\mathrm{Ra})] \\
& \mathrm{k}=\frac{\mathrm{Ra}(\mathrm{n}+1)^{2}-(\mathrm{n}-1)^{2}}{\mathrm{n}^{2}(1-\mathrm{Ra})}
\end{aligned}
$$

Where $\mathrm{Ra}$ and Ro are the reflectances of the sample in air and oil, n, na and no are respectively the refractive indices of the sample, air and immersion oil, and $\mathrm{k}$ is the absorptive index of sample.

Graptolites show two types of textures under reflected light; a) nongranular fragments which appear hard, brittle and often show fine structural detail, for example lamination, b) granular which is fine granular to reticular. The nongranular fragments show higher anisotropy than the granular fragments (Goodarzi 1984). Goodarzi \& Norford (1985) have described the morphology

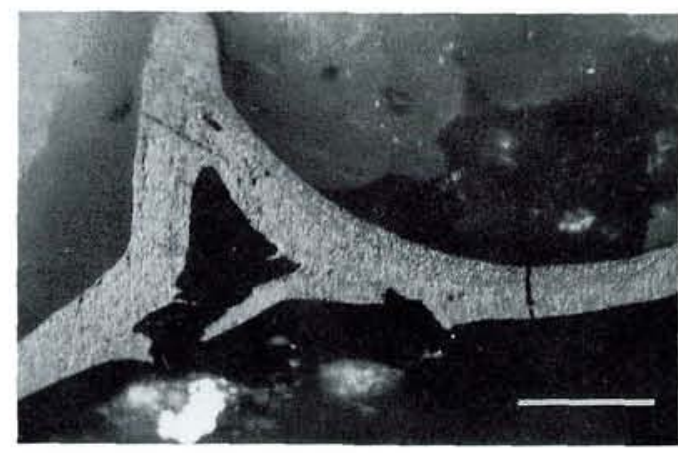

Fig. 1. Fragment with granular surface, lower Silurian argillaceous limestone, Cape Phillips Fm., Canadian Arctic. Plane polarised scale bar is $50 \mu \mathrm{m}$.

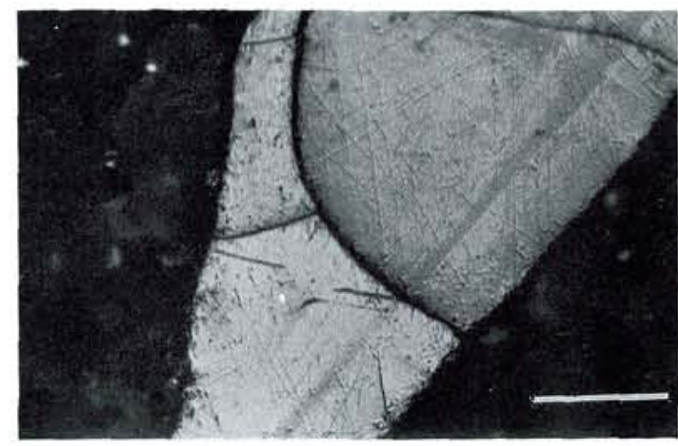

Fig. 2. Nongranular fragments, middle Ordovician shale Glenogle Shales, British Columbia. Partially crossed polars. Magnification same as Fig. 1 . 


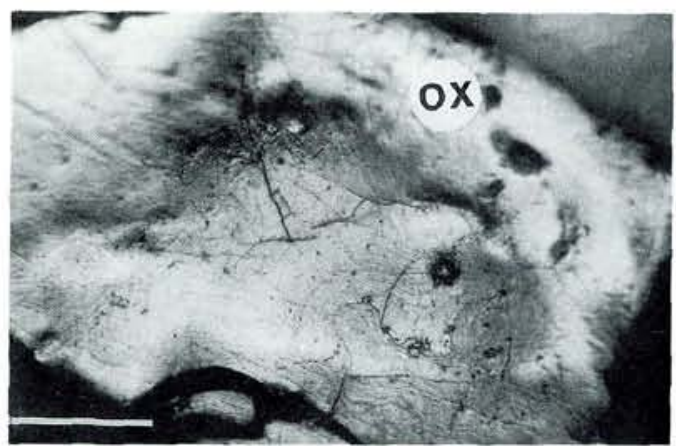

Fig. 3. Weathered fragments, Oxidation rim $(O x)$ has higher relief and reflectance than the unaltered central area, lower Silurian dolomitic silty shale, Road River Group, British Columbia. Oil immersion plane polarised. Magnification same as Fig. 1.

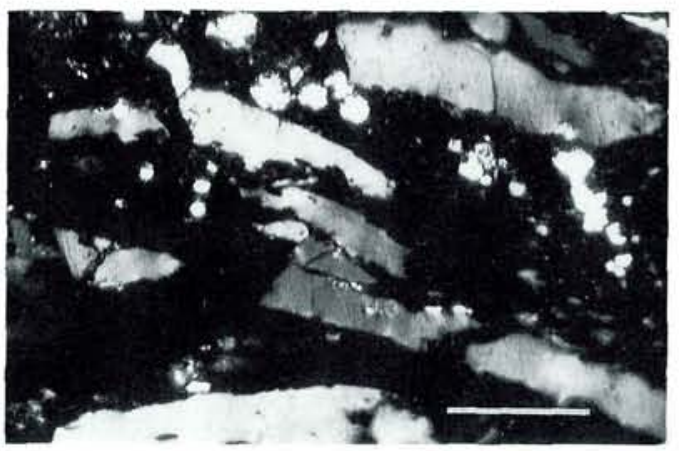

Fig. 4. Mineralized graptolite, nongranular strongly anisotropic, lower Silurian mineralized shale, Road River group, Yukon Territory. Partially crossed polars. Magnification same as Fig. 1.

of a range of Canadian graptolites found in sedimentary rock: shales, marls, limestones, cherty rocks, also in weathered and heat affected rocks. Graptolites in carbonate were granular (Fig. 1) but those in shale were often nongranular (Fig. 2). Anisotropy of graptolites in shale were higher than those found in carbonate. A weathered graptolite displayed an oxidation rim of higher reflectance than the graptolite matrix (Fig. 3), and graptolite fragments found in rocks subjected to mineralization and hence perhaps subjected locally to high temperature by mineralizing solution were nongranular showing very high anisotropy (Fig. 4).

Goodarzi (1984) and Goodarzi \& Norford (1985), Goodarzi et al. (1985), have compared the morphology of fragmentary graptolites to those of arcritarchs, bitumen, chitinozoans and sclecodonts. Graptolite fragments showed higher anisotropy than other dispersed organic material in the same sediment.

\section{Optical properties}

Optical properties of graptolites have been studied by Kurylowicz et al. (1976), Teichmüller (1978), Clausen \& Teichmüller (1982), Goodarzi (1982, 1984, 1985b), Goodarzi \& Norford (1985), and Goodarzi et al. (1985). Kurylowicz et al. (1976), Teichmüller (1978) and Clausen \& Teichmüller (1982) have determined the reflectance and bireflectance of a range of graptolite. Kurylowicz et al. (1976) have examined graptolites found in some central Australian sediments (Ordovician-Devonian). The maximum range of reflectance in oil was $0.80-2.37 \%$ with bireflectance of $0.35-1.05$.

Teichmüller (1978) determined the reflectance of graptolite cortex found in the Ordovician of a borehole in NW-Germany (5.1-10.0\% Rmax) as well as from graptolites found in boulders from the Baltic Sea $(0.8 \%$ Rmax $)$, from Brittany (1.7\% Rmax), from Thuringia $(8.2 \% \mathrm{Rmax})$ and from Spain $(9.2 \%$ Rmax). Clausen \& Teichmüller (1982) found that the maximum oil reflectance of graptolites from the borehole in NWGermany increases with depth. They also report reflectance values of a range of graptolites from Sweden. The Swedish graptolites had reflectances of $0.36-0.72 \% \mathrm{Rm}$, whereas the reflectances for graptolites from the borehole SoestErwitte 1/1a ranged from $6.0-10.5 \%$ Rmax.

Goodarzi $(1982,1984)$ determined the reflectance and bireflectance of Turkish graptolites (Ordovician-Silurian) and found that the reflectance of graptolites increased with depth and also that graptolites had higher reflectance than natural bitumen or chitinozoans (Goodarzi 1984, 1985a), (Fig. 5). Further, Goodarzi (1984) determined the dispersion of maximum and minimum oil reflectances of graptolites from Turkey parallel and perpendicular to bedding to determine the optical character of graptolites (Fig. 6). Teichmüller (1978) stated that the graptolites found in the highly foliated schists of the borehole SoestErwitte may have a biaxial optical character. Goodarzi (1985b) found that the dispersion of oil reflectance of both granular and nongranular 


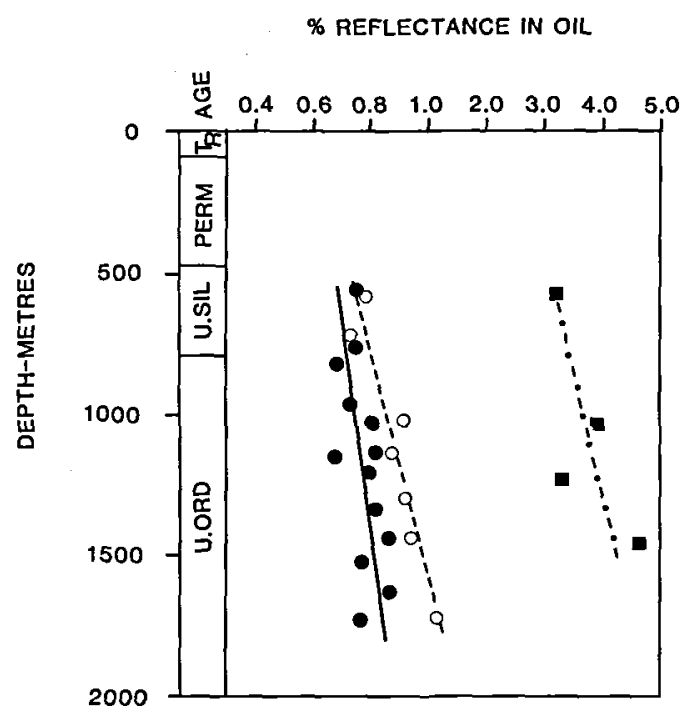

Fig. 5. Maximum reflectance in oil of bitumen ( $\Theta$ ), Chitinozoan $(O)$ and graptolite $(\mathbb{Q})$ versus depth for a borehole in southeast Turkey. (Redrawn after Goodarzi, 1984, 1985a).

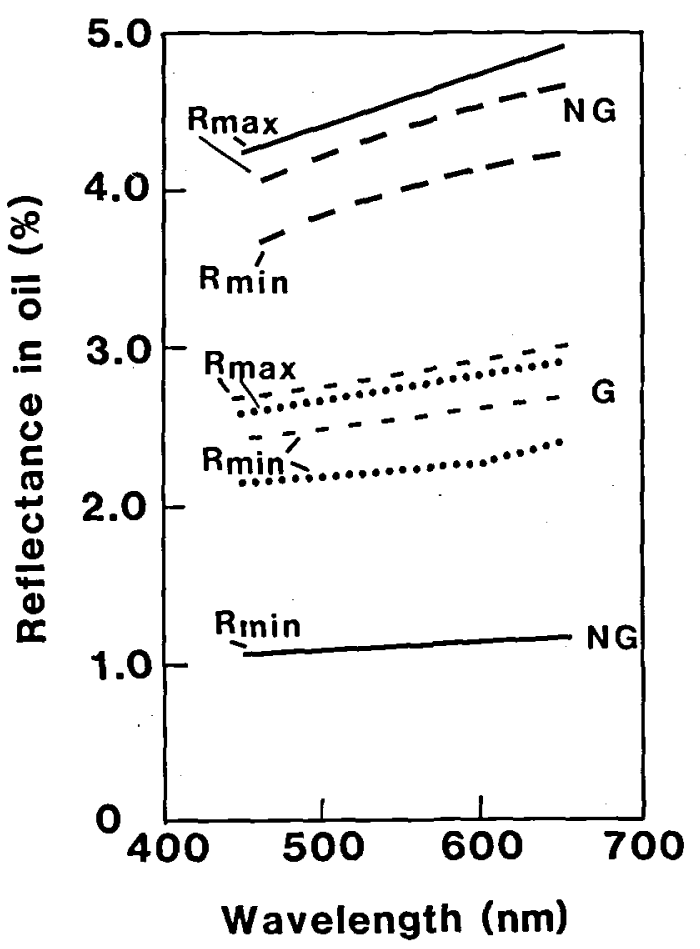

Fig. 6. Dispersion curve of maximum and minimum oil reflectance for nongranular (NG) and granular (G) graptolite fragments. Nongranular in section parallel - and perpendicular to bedding - - granular in section parallel...- and perpendicular to bedding .... (Redrawn after Goodarzi, 1984).

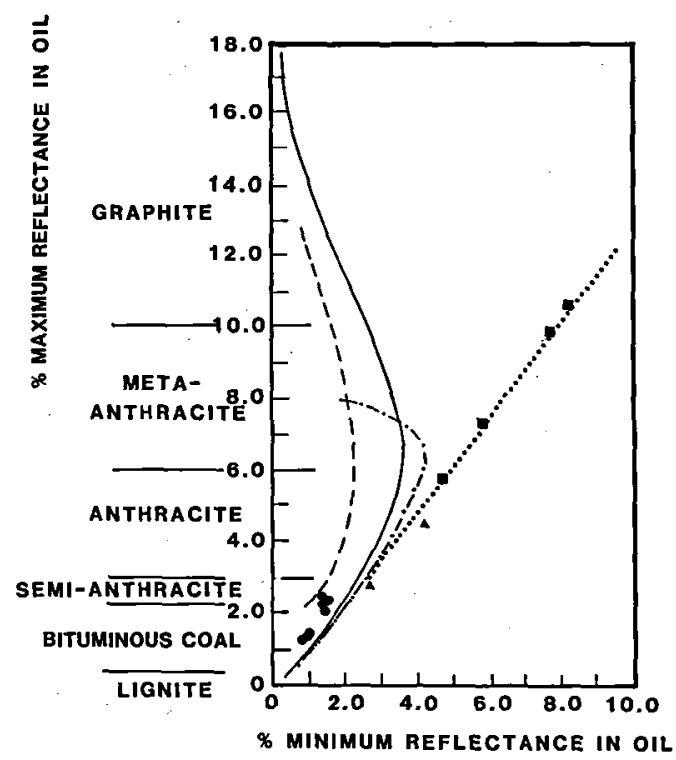

Fig. 7. Maximum versus minimum reflectance trend for coal graphite - , heat affected coal---, bitumen - - , and graptolite ... after Kurylowicz et al. 1976, O after Clausen \& Teichmüller 1982, $\boldsymbol{\Xi}$ after Goodarzi $1984 \boldsymbol{\Lambda}$.

graptolite epiderm for sections both parallel and perpendicular to bedding increased with increasing wavelength, similar to anthracite (Davis 1978). However, both the maximum reflectances and bireflectances of nongranular graptolites were higher than those of granular graptolites (Fig. 6).

Goodarzi (1984) compared the maximum versus minimum oil reflectances of coal, heat affected coal and natural bitumen with those for graptolites determined by Kurylowicz et al. (1976), Clausen \& Teichmüller (1982), (Fig. 7).

Goodarzi \& Norford (1985) examined the optical properties (reflectances in oil and air, bireflectance in oil, refractive and absorptive indices at wavelength $546 \mathrm{~nm}$ ) for a range of Canadian graptolites (Ordovician-Silurian) that had known conodont alteration indices. They found that a) optical properties of graptolites changed progres sively with increasing of thermal maturation (conodont alteration index); b) graptolites in shales had higher reflectance and bireflectance than those in carbonate; $c$ ) reflectances of weathered graptolites were higher in oxidation rims than in unaltered cores; and d) the optical properties of graptolites found in a mineralization zone were elevated compared to those of grapto- 
lites from non-mineralized rocks with the same conodont alteration index.

\section{Dispersion of optical properties of graptolite}

Goodarzi (1985b) determined the dispersion of optical properties (reflectance in air and oil, refractive and absorptive indices) in visible light (wavelengths 450-650 $\mathrm{nm}$ ) for graptolite epiderm (Ordovician-Silurian) with low to high maturity levels (conodont alteration index $=1-5$ ). The dispersion of optical properties of graptolite fragments in sediments follows similar trends to those of bitumen and pyrobitumens, and also of coal macerals. This indicates that graptolite epiderm undergoes similar molecular structural changes, for example an increase in aromaticity and ordering of aromatic carbon with increased thermal maturity.

The dispersion of optical properties of graptolites falls into three types of spectral patterns: -

1) In low maturity graptolites, the reflectance, refractive and absorptive indices curves fall from blue (400 $\mathrm{nm}$ wavelength) to red (700 $\mathrm{nm}$ wavelength) (Fig. 8) indicating low aromatic carbon. This is similar to dispersion pattern of low rank vitrinites (Marshall \& Murchison, 1971; Davis,

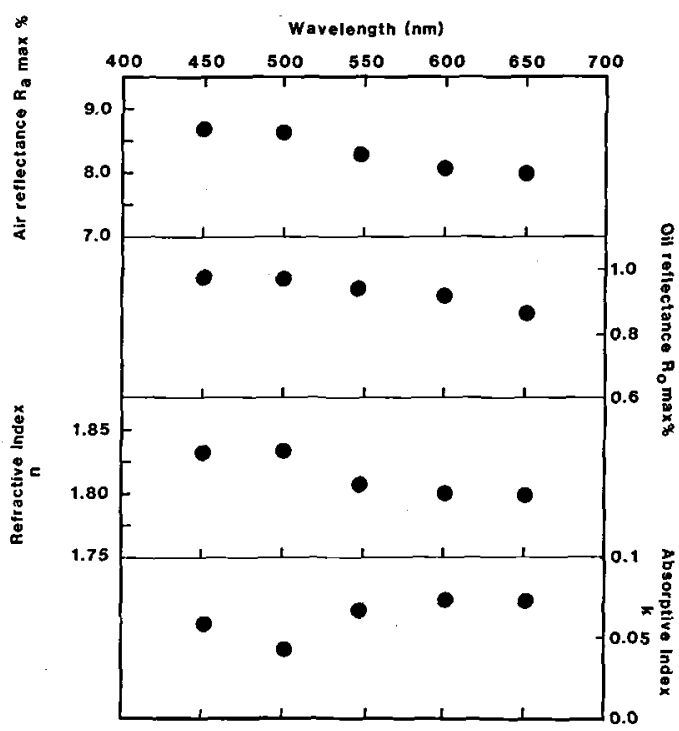

Fig. 8. Dispersion of optical properties of low maturity graptolite (conodont alteration index $=1$ ).

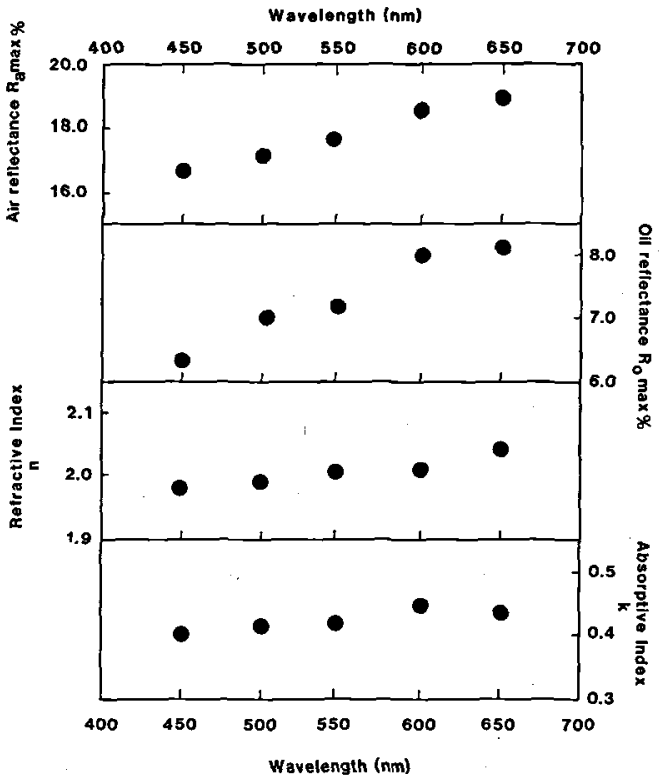

Fig. 9. Dispersion of optical properties of moderately matured graptolite (conodont alteration index $=3 \frac{1}{2}$ ).

1978) and asphaltic bitumens (Khavari-Khorasani \& Murchison, 1977).

2) In moderately matured graptolites the reflectance curves become almost flat, whereas the refractive indices rise from blue to red (Fig. 9),

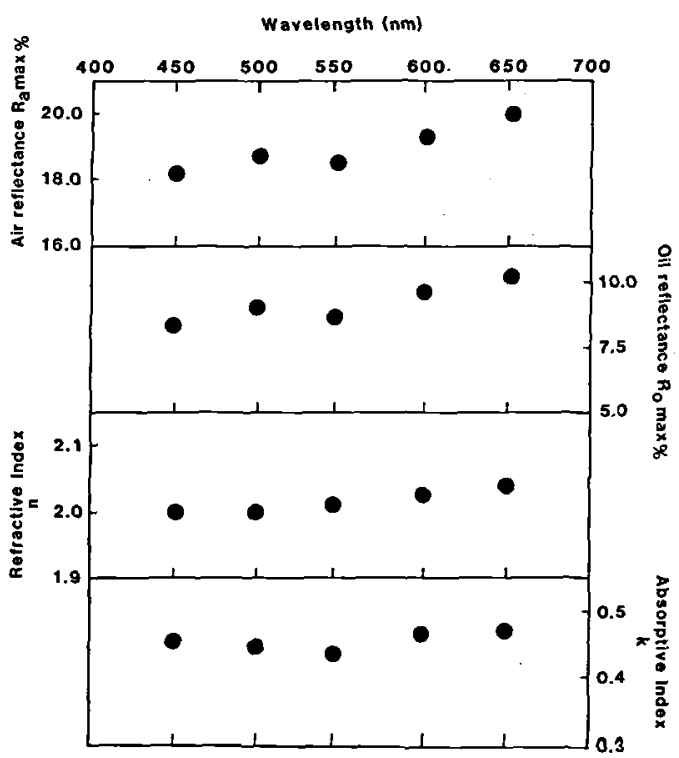

Fig- 10. Dispersion of optical properties of highly matured graptolite (conodont alteration index $=4 \frac{1}{2}$ ). 
indicating of moderate aromaticity and ordering of aromatic carbon. This pattern is similar to dispersion pattern for semi-anthracites and impsonites (Khavari-Khorasani \& Murchison, 1977, Davis, 1978).

3) In highly matured graptolites the reflectance, refractive and absorptive indices rise continuously from blue to red (Fig. 10). This is similar to the dispersion pattern for anthracites, meta-anthracites, shungites, anthraxolites (Marshall and Murchison 1971, Cook, Murchison and Scott 1972, Khavari-Khorasani and Murchison 1977, Davis 1978). The rise of the spectral pattern from blue to red indicates high aromaticity and transformation of polynuclear aromatic structure to mesomorphic or graphitic structure (Goodarzi 1985b).

\section{Application of maturation study of graptolite in oil exploration}

Early Palaeozoic (Cambrian-Silurian) sediments do not contain vitrinite (kerogen type III, Brooks 1981). However these sediments often contain bitumen-pyrobitumen and organic fossils, for example acritarchs, chitinozoans, scolecodonts, and graptolites (Goodarzi, 1984, 1985a-b; Goodarzi \& Norford, 1985; Goodarzi et al. 1985).

Reflectances of graptolites are higher than those of other organic fossils or bitumens from the same sediment (Goodarzi et al. 1985). Dispersion of optical properties of graptolite epidermis follows similar trends to that of vitrinite with increasing coalification (Goodarzi, 1985b). Further, the oil reflectance of graptolite increases with depth similar to that of vitrinites (kerogen type III) (Brooks, 1981). Comparison between reflectance versus depth for natural bitumens, chitinozoans and graptolite fragments found in the same samples (Fig. 5) indicate that reflectance/depth trends for chitinozoans follow a higher trend than those for natural bitumens, but lower trends than those for graptolites. Direct comparison of reflectances of bitumens to those of vitrinites is not possible for lower Palaeozoic sediments due to the absence of vitrinites in these rocks (Goodarzi 1982). However, bitumens show lower reflectances than vitrinites in younger sediments in the low rank stage. Reflectances of bi- tumens (RoB) is about $0.2 \%$ less than those of vitrinites up to reflectances of $1.0 \%$ (vitrinite), then a reflectance higher than that of vitrinites developes (Robert, 1980). Hence the reflectance values of graptolites increase with depth from 3.2 to $4.8 \%$ Rmax according to Fig. 5. Based on the reflectance of bitumen and of chitinozoan, reflectance values of graptolites in the order of 3-4\% Rmax indicate a late stage of hydrocarbon generation to overmaturity.

Goodarzi et al. (1985) examined the source rock potential of sediments from the Grand Banks, offshore Atlantic Canada, using RockEval and the reflected light microscope. They found that some of the samples that contain bitumens ( $\% \mathrm{R}$ oil $=0.17$ and 1.42$)$ and graptolites $(\% \mathrm{R}$ oil $\max =4.0)$ have potential for hydrocarbon.

\section{Conclusions}

1) Graptolite epiderm consists of nongranular and granular components.

2) The reflectance of graptolite epiderm increases with depth.

3) The spectral trends of optical properties of graptolite epiderms follow similar trends to those for bitumens and coal macerals with increasing maturation, indicating similar molecular changes.

4) The graptolite epiderm can be used as an indicator of the thermal maturation of its host sediment.

Acknowledgements. We appreciate and extend our thanks for critical reviews of the manuscript to Dr. M. Teichmüller, F. G. R. Krefold, and Dr. A. R. Cameron, Geological Survey of Canada, Calgary.

\section{Dansk sammendrag}

Optiske egenskaber, baseret på reflekteret lys af graptolitters organiske materiale, andres med stigende temperatur. Faktorer, som er vigtige for varmepåvirkningen omfatter mægtigheden af den oprindelige overliggende lagpakke, metamorfose og tektonik, sammensætningen af matrix, mineralisering samt oxidation.

Undersøgelser i Canada baseret på nedre ordoviciske til øvre silure graptolit-førende aflejringer bliver sammenlignet med "Conodont Farve Index « (CAI). CAI er benyttet som standard reference ved temperaturbestemmelse, og anvendes til modenhedsbestemmelse af sedimenter. 
Disse data viser, at andringen af graptoliters optiske egenskaber, med stigende temperatur er en alternativ eller supplerende metode til CAI ved bestemmelse af temperaturen der har påvirket sedimentet. Metoden er især pålidelig ved højere varmegrader.

\section{References}

Brooks, J. 1981: Organic Maturation of sedimentary organic matter and petroleum exploration. A review In: Organic maturation studies and fossil fuel exploration. (Ed. Brooks, J.) Academic Press, London, 1-38.

Clausen, C. D. \& Teichmüller, M. 1982: Die Bedeutung der Graptolithen fragmente in Paläozoikum von Soest - Erwitte für Stratigraphie und Inkohlung, Fortschr. Geol. Rheinld. U. West, 30, 145-67.

Cook, A. C., Murchison, D. G. \& Scott, E. 1972: A British meta-anthracite coal of Denovian age, Geological Journal $8,1,83-94$

Davis, A. 1978: The reflectance of coal. In: Analytical methods for coal and coal products (Ed. Karr, C.), Academic Press, London, Vol. 1, p. 27-78

Goodarzi, F. 1982: A brief hydrocarbon potential study of southeast Turkey using organic petrography, Report to Turkish petroleum research centre, Ankara, Turkey. $28 \mathrm{pp}$.

Goodarzi, F. 1984: Organic petrology of graptolite fragments from Turkey. Marine and Petroleum Geology, 1, 202-210.

Goodarzi, F. 1985a. Reflected light microscopy of chitinozoan fragments. Marine and Petroleum Geology, 2, 72-78.

Goodarzi, F. 1985b: Dispersion of optical properties of graptolites with increased maturity in early Paleozoic organic rich sediments. Fuel, 64, 1735-1740.

Goodarzi, F. \& Norford, B. S. 1985: Graptolites as indicators of the temperature histories of rock. J. Geol. Soc. London, $142,1089-1099$.
Goodarzi, F., Gunther, P. R., Jenkins, W. A. W. \& Snowdon, L. R. 1985: Preliminary organic petrology of paleozoic rocks from the Grand Banks, Newfoundland. Marine and Petroleum Geology, 2, 254-259.

Khavari-Khorasani, F. \& Murchison, D. G. 1977: Application of light microscopy in structural studies of bitumens. International Committee for Coal Petrology meeting, Essen. pp. 10.

Kurylowicz, L. E., Ozimic, S., McKirdy, D. M., Kantsler, A. J. \& Cook, A. C. 1976: Reservoir and source rock potential of the Larapinta Group, Amadeus Basin, Central Australia. Australian Petroleum Exploration Association Journal, 16, 49-65.

Kwiecinska, B., Murchison, D. G. \& Scott, E. 1977: Optical Properties of Graphite. Journal of Microscopy 104 (3), 294-302.

Mackowsky, M. Th. 1982: Preparation of polished surfaces from particulate samples. In: Coal Petrology (Eds. Stach, E., Mackowsky, M. Th., Teichmüller, M., Taylor, G. H., Chandra, D., Teichmüller, R.). Gebrüder Borntraeger, Berlin, 296-299.

Marshall, R. J. \& Murchison, D. G. 1971: Dispersion of optical properties of carbonised vitrinites. Fuel, 50, 4-22.

Robert, P. 1980: The optical evaluation of kerogen and geothermal histories applied to oil and gas exploration. In: Kerogen (Ed. Duran, B.), Technips, Paris, 385-414.

Teichmüller, M. 1978: Nachweis Von Graptolithen-Periderm in geschieferten Gesteinen mit Hilfe kohlen petrologischer Methoden. N. Jb. Geol. Paläont. Mh., 1978, 430-477.

Teichmüller, M., Teichmüller, R. \& Weber, K. 1979: Inkohlung und Illit-Kristallinität. Fortsch. Geol. Rheinld. U. West 27, pp. 201-276.

VanGijzel, P. 1975: Polychromatic UV-fluorescence microphotometry of fresh and fossil plant substances, with special reference to the location and identification of dispersed organic material in rocks, $I n$ : Colloque International Pétrographie de la matiere organic des sediments, relations avec la paléotempérature et le potentiel petrolier, Paris, 1973, (Ed. Alpern, B.), Vol. 1, 67-91). 